\title{
PADRÕES DE CARREIRA E FORMAS DE RECONVERSÃO DA MILITÂNCIA POLÍTICO- PARTIDÁRIA
}

\author{
CAREER PATTERNS AND WAYS OF RECONVERTING POLITICAL AND PARTY MILI- \\ TANCY
}

\begin{abstract}
Resumo:
A sociologia das elites tem dedicado fundamental atenção aos estudos relacionados ao processo de seleção e ascensão daqueles que ocupam posições de destaque em diferentes espaços. Buscando contribuir com esse debate, o presente trabalho apresenta parte dos resultados de uma pesquisa mais ampla, a respeito do processo de recrutamento e seleção de líderes de partidos políticos. Os dados colhidos na pesquisa permitiram apreender o perfil do grupo considerado, os diferentes padrões de carreira e de reconversão de recursos de diferentes origens e o peso que exercem no tocante acesso aos postos de comando disponíveis no interior do partido. $O$ estudo demonstrou que os líderes que compõem o Partido Verde se assemelham a outras elites partidárias, sobretudo, quando se tratando de origens familiares e categorias profissionais, mas também demonstrou que lidamos com um grupo relativamente singular, desprovidos daquilo que poderíamos chamar de capital político e militante, recursos importantes para a ascensão em qualquer espaço do universo político. A hipótese da qual se assenta esse artigo é a de que o grupo analisado faz uso de atributos como capital social e cultural, que lhes permite tanto a entrada e ascensão no partido quanto a reconversão desse envolvimento partidário, a partir da ampliação das redes de relações que potencializam suas chances de ocupação profissional. $O$ universo empírico do qual trata esse trabalho é composto pelos líderes do Partido Verde, seccional Sergipe. Trata-se de uma pesquisa qualitativa, cujas informações foram acessadas por meio de entrevistas semiestruturadas.
\end{abstract}

Palavras-chave: Padrões de carreira. Liderança político-partidária. Reconversão. Partido Verde.

I Doutor em Sociologia pela Universidade Federal de Sergipe. E-mail: bergsonvieira@hotmail.com.

2 Doutor em Sociologia pela Universidade Federal de Sergipe. E-mail: max_alex86@hotmail.com. 


\begin{abstract}
The sociology of elites has devoted prime attention to studies related to the process of selection and rise of those who occupy prominent positions in different spaces. Seeking to contribute to this debate, this paper presents part of the results of a broader research on the process of recruiting and selecting political party leaders. The data collected allowed to determine the profile of the considered group, the different career patterns, the conversion of resources from different origins and the weight they exercise regarding access to the command posts available within the party. This study showed that the leaders that make up the Green Party resemble other party elites, especially when it comes to family backgrounds and professional categories, but it also demonstrated that it is a relatively unique group, devoid of what we would call political capital and militancy, important resources for the rise in any space of the political universe. The hypothesis of this article is that the analyzed group makes use of attributes such as social and cultural capital, which allows them both to enter and rise in the party, as well as the reconversion of this party involvement based on the expansion of the networks of relationships that enhance one's chances of professional occupation. The empirical universe comprising this study are the leaders of the Green Party, sectional Sergipe. This is a qualitative research whose information was accessed through semi-structured interviews.
\end{abstract}

Keywords: Career patterns. Political-party leadership. Reconversion. Green Party.

\title{
INTRODUÇÃO
}

O presente trabalho apresenta parte dos resultados de uma pesquisa mais ampla ${ }^{3}$ a respeito do processo de recrutamento e seleção de líderes ${ }^{4}$ de partidos políticos. Os dados colhidos na pesquisa permitiram apreender o perfil do grupo considerado, sobretudo, no que diz respeito às origens sociais, recursos culturais e profissionais. Enfim, permitiu-nos identificar a composição social do partido político analisado. A partir dessas informações passamos a objetivar uma análise das diferentes modalidades de carreira e de reconversão dos recursos sociais dos líderes e/ou dirigentes, ${ }^{5}$ no sentido de analisar os mecanismos que transformam diferentes recursos (sociais, escolares e profissionais) em "trunfo" que permite a inserção do grupo aos postos de comando disponíveis no

3 Dissertação de mestrado cujo título é "Recrutamento e Seleção de Elites partidárias em Sergipe: o caso dos líderes do Partido Verde", defendido em 30 de agosto de 2013.

4 O universo empírico do qual trata esta pesquisa é composto pelos dirigentes do PV. Conquanto, para uma melhor explicitação dos agentes considerados para os fins da pesquisa, são considerados os ocupantes dos seguintes cargos no referido partido: 1) Presidente;2) Vice-presidente;3) Secretário de Organizações; 4) Secretário de Finanças; 5) Secretária da Mulher; 6) Secretário de Comunicação; 7) Secretário de Formação; 8) Secretário Jurídico; 9) Secretário da Juventude; 10) Secretário da Mobilização; e 11) Secretário de Administração.

5 No texto as expressões líderes e dirigentes serão usadas como sinônimos. Portanto, serão usadas em diferentes pontos do trabalho para expressar a mesma coisa, que é a posição de destaque no partido. 
partido. Para isso, o texto apresentará três diferentes itinerários ${ }^{6}$ que ajudam a entender as formas de acesso aos postos disponíveis pelo partido. Considerando, enquanto universo empírico, os líderes do Partido Verde (PV), seccional Sergipe.

Os trabalhos que lidam com essa problemática (BOURDIEU, 1980; 2007; 2011; CORADINI, 1996; 2001; GAXIE, 1977; PETRARCA, 2007; OLIVEIRA, 2008a; 2008b) demonstram que as posições de chegada têm a ver com determinantes de bases sociais, à exemplo das origens sociais, a inserção em espaços de socialização, assim como a inserção profissional. Esse postulado nos leva a um conjunto de implicações que se assentam no princípio segundo o qual a posição ocupada no interior do partido resulta de um conjunto considerável de recursos acessados por meio do trânsito em diferentes espaços sociais. Recai sobre essa premissa o principal desafio desse texto, qual seja: a de que o líder partidário é um sujeito imerso em uma rede de relações constituída ao longo de sua vida (FILLIEULE, 2001) e são, portanto, pessoas com origens sociais (grupo familiar e escolar), origens associativas (movimentos sociais, religiosas, entre outras) e origens profissionais singulares diferentes. São sujeitos ímpares e a posse de diferentes recursos e/ou trunfos não são apenas condicionantes para a entrada no partido, como também ampliam ou não a possibilidade de reconversão dos recursos (adquiridos antes, durante ou depois da passagem no partido).

Os dados revelam que os líderes do PV se assemelham a outras elites partidárias, sobretudo, quando se tratando de origens familiares e categorias profissionais. (RODRIGUES, 2009) O estudo também demonstrou que estamos tratando de um grupo bastante singular, desprovido do que poderíamos chamar de capital político e militante, recursos importantes para a ascensão em qualquer espaço do universo político. Nossa hipótese é a de que o grupo analisado faz uso de atributos como capital social e cultural que lhes permite tanto a entrada e ascensão no partido, quanto a reconversão desse envolvimento partidário a partir da ampliação das redes de relações que potencializam suas chances de ocupação profissional ${ }^{7}$ relacionada ao saber político.

6 Os padrões de carreira apresentados ao longo do artigo foram definidos pelo pesquisador a partir de um trabalho de campo e um conjunto de entrevistas, ambos realizados entre março e outubro de 2012. Nesse período observou-se uma maior incidência de frequentadores no escritório, isso em função das eleições daquele ano, ocasião na qual o partido lançou o nome de Reynaldo Nunes (à época presidente estadual do partido), ao posto executivo municipal da Capital Aracaju-SE.

7 Sobre isso, ver em especial Weber (2003), em que o autor esmiúça a relação entre saber profissional e política, destacando algumas categorias profissionais tais como bacharel em direito, engenharias, professores, jornalistas como sendo favoráveis à aquisição de saberes que podem se converter em saber político. 
A estratégia de análise e levantamento de dados nos permitiu compreender as divisões do grupo considerado, assim como os princípios de entrada e ascensão na hierarquia do partido. Para tanto, nossa proposta precisou considerar dois níveis de análise: num primeiro nível, se fez necessário categorizar os dirigentes dentro de uma ordem dos prováveis, ou seja, encontrar padrões e lógicas de investimentos que expliquem o acesso aos postos de destaque no PV e; num segundo nível, identificarmos as retribuições materiais e imateriais que esses podem ter acesso em função da posição ocupada no partido. Em relação a essas dimensões analíticas alguns trabalhos são considerados. (CORADINI, 1996; 2001; GAXIE, 1977; OLIVEIRA, 2008a; 2008b; PÉCHU, 2007; PETRARCA, 2007; SAINTENY, 1999; SEIDL, 2009) Eles demonstram que, em se tratando de sujeitos imersos em diferentes modalidades de organizações associativas, o fato de ocupar postos de destaque lhes permite estabelecer redes de relações que podem se converter em "trunfos" a serem usados em momento oportuno. Esses "trunfos" (ou recursos) não necessariamente se restringem à esfera profissional, mas também podem ser acionados em outras esferas sociais.

A partir do estudo mais amplo foi possível identificar três padrões de recrutamento: militantismo real, política por vocação e categorias profissionais. Nem todos que se engajam em partidos políticos objetivam acesso às disputas eleitorais, nem tampouco às retribuições materiais que o partido pode dispor, e isso pode ser observado no primeiro padrão observado (militantismo real). Para esses líderes os partidos funcionam como espaço de satisfação, de defesa de um ideal, de ter um compromisso, de modo que o partido se torna um ambiente de socialização e de inserção em grupos de amigos dispostos a falar de assuntos referentes à política e ao partido. (GAXIE, 1977) Para esse padrão de dirigente ativista - não significa dizer que os outros não o sejam - o ativismo no partido representa uma parte significativa de sua vida. É ele quem mais frequenta as dependências do diretório estadual, participa das reuniões, se dedica em organizar campanhas políticas de seus companheiros de partido, entre outras funções. Por possuir uma lógica de engajamento diferente daquela que pretendemos debater aqui, esse padrão não será analisado com maior atenção, nos atendo aos dois padrões restantes: político por vocação e categorias profissionais. 


\section{PADRÃO I: POLÍTICOS POR "VOCAÇÃO” OU TENTATIVAS DE AQUISI- ÇÃO DE UM CAPITAL POLÍTICO?}

O caso a ser apresentado tem uma importância para o estudo em pauta, na medida em que representa o recrutamento de "dirigentes-políticos", ou seja, de líderes que se inserem no ambiente do partido visando exclusivamente maiores oportunidades para disputar eleições. Como ponto de partida, conforme já demonstrado em outro lugar (VIEIRA, 2012), o fato de ocupar postos de destaque no partido favorece os dirigentes no momento de escolha de representantes ${ }^{8}$ para às eleições. Isto é, dentro de um universo de "aspirantes" à representante do partido no pleito, o fato de ser dirigente serve de distinção entre este e os demais que são apenas filiados, não raro, esses dirigentes são favorecidos em momentos de crise e de escolhas de representantes. Outra questão, igualmente importante, tem a ver com o fato de que, mediante a posição ocupada dentro do partido e das exigências que essa posição requer, esses dirigentes passam a adquirir um savoir-faire político. Ou, dito de outra forma, estar no partido ocupando postos de destaque permite a esses o acesso a uma "gramática de grupo" de modo que, tanto os saberes adquiridos quanto a posição ocupada, possam ser acionados durante o pleito enquanto "trunfo" político.

O primeiro caso é o de um dirigente, atualmente com 43 anos, proveniente de uma família de políticos, tendo convivido durante sua infância e adolescência com seu avô paterno o qual exercera três mandatos de prefeito em uma cidade do interior, isso entre às décadas de 1960 e 1970. Trata-se de Simão Dias, cidade do agreste sergipano, segundo dados do IBGE/2012, com aproximadamente 38.988 mil habitantes e classificada como uma pequena cidade. Em função desse contato (entrevistado/avô), o entrevistado se diz "herdeiro" político de seu avô, pretendendo "seguir seus passos" e "servir ao próximo como ele serviu". Chama atenção, neste caso, o fato de seu pai não ter dado continuidade a "carreira" política do progenitor, pois, em virtude dessa ruptura por parte de seu genitor, o entrevistado perderia o reconhecimento social da "herança"

$8 \quad$ Alguns trabalhos têm se esforçado para analisar o papel dos partidos na sociedade. Por um lado, temos trabalhos que partem do princípio de que os partidos seriam uma espécie de link entre a sociedade e o universo político, assim, esses funcionariam enquanto instituições capazes de formar uma elite especifica, a saber, a própria elite política. (DUVERGER, 1980; WEBER, 2003) No geral, esses trabalhos convergem no sentido de indicar que o recrutamento aconteceria de baixo para cima, de modo que os membros recrutados para compor a elite política seriam recrutados das bases sociais e, como consequência, dentro deste esquema, esses partidos deveriam representar variados grupos dessa mesma sociedade, fazendo valer o direito dos grupos sociais de serem representadas em sua plenitude por parlamentares. Por outro lado, temos uma linhagem de estudos que apresentam os partidos enquanto instituições autônomas e não subordinada à sociedade, assim, seus representantes tendem a representar os anseios do partido e não os grupos sociais. Dentro dessa lógica, nos partidos ocorreria uma "filtragem" por meio da qual o amplo universo de "selecionáveis" (aspirante aos cargos eletivos) seria reduzido, pelos "seletores" (líderes) partidários, a um universo bem menor de aspirantes e candidatos. (PERISSINOTTO; MIRÍADE, 2009) 
política da família. Nesse sentido, o trajeto social desse agente demonstra algumas tentativas de, por um lado, acessar os bens simbólicos advindos do reconhecimento social dessa "herança" e, por outro lado, de alcançar seus objetivos de ocupar um cargo eletivo em sua cidade. A questão que interessa saber é: em que medida ser dirigente do PV permite ao entrevistado a possibilidade de ter acesso a seus anseios políticos.

Trata-se, portanto, da trajetória social do Entrevistado I. ${ }^{9}$ Sua carreira política iniciou-se quando tinha 21 anos de idade. É pertinente destacar que esta carreira se deu, exclusivamente, através de filiações em partidos políticos, ou seja, tal como outros dirigentes do partido, não se observou em sua trajetória qualquer tipo de engajamento militante, participação em movimentos estudantis que demonstrasse associação em organizações não partidárias. Seu único envolvimento é o religioso de viés kardecista, religião esta que segue desde muito cedo, depois que completou 17 anos de idade, o que contrariava alguns membros de sua família, de maioria católica.

Suas principais referências na política advêm, mesmo, do ambiente familiar. Ocorre que esse entrevistado é bisneto e neto de políticos que ocuparam em momentos diferentes o posto máximo do executivo municipal. Seu bisavô, Leopoldo Araújo de Sousa, foi prefeito por três mandatos (1930, 1935 e 1937) e seu avô, Raimundo Oliveira Sousa, também conhecido na região como "seu Raimundinho", à exemplo do pai, também se envolverá com a política local, sendo eleito prefeito também por três vezes (1946, 1967 e 1973). Em função dessa referência "caseira", o entrevistado apresenta sua família como uma família de "políticos natos" de modo que a política estaria "no sangue" de seus membros.

Embora não tenha conhecido seu bisavô, viveu com seu avô até os 18 anos de idade quando este "veio a desencarnar". Para o entrevistado, o período vivido ao lado de seu avô foi de fundamental importância para sua politização, pois lhe permitiu a aquisição de um "entendimento da política" e de saberes que faria parte de sua vida pública. Todavia, apesar dessa "linhagem" política bem definida, seu pai não se envolve com essa atividade, rompendo com uma "carreira" de bases familiares. Essa ruptura vai repercutir diretamente na carreira política de nosso entrevistado, ocorre que ele passaria a buscar o reconhecimento social de sua "herança" política através do acionamento de sua ligação com seu avô. Aliás, no decorrer de sua fala, o entrevistado demonstrava seu ponto de vista a respeito do não envolvimento de seu pai com a política, como diz:

9 Faremos uso da nomenclatura apresentada no sentido de preservar a identidade dos agentes entrevistados, a apresentação de algumas de suas características, bem como da posição que ocupa no partido será dada ao final do texto. 
"meu pai não se envolveu por fraqueza, por medo", demonstrando total aversão ao posicionamento de seu pai. O fato é que seu tio (irmão de seu pai) teria dado continuidade na "carreira" política da família, disputando e sendo eleito vereador desse município por dois mandatos (1992 e 1996), por sinal, o primeiro mandato de seu tio coincide com o tempo em que o entrevistado iniciou sua carreira eleitoral. Tal acontecimento levou a uma disputa entre familiares, tornando-se rivais políticos no município, fato este associado à busca pelo reconhecimento dos laços familiares, ou seja, quem pode se apresentar como legítimo "herdeiro" de seu Leopoldo (bisavô) e seu "Raimundinho" (avô). A esse respeito, tal como observa Canedo (2005), os laços familiares podem ser convertidos em capital político, porém essa conversão não se dá de maneira automática, contrário disso, a transmissão da "herança" familiar e sua reconversão em recurso político só pode obter êxito através do acionamento desses laços, de modo que a sociedade possa assimilar e associar a relação entre uma família política e seus respectivos membros.

À exemplo de tantos outros sergipanos, sua trajetória é marcada por um deslocamento geográfico caracterizado pela saída de sua cidade natal para Aracaju. Fato justificado em função de suas atribuições profissionais, ocorre que, no final da década de 1990, exercia um cargo comissionado de oficial de justiça, sendo transferido dessa cidade para Aracaju em função de mudanças políticas ocorridas no município. Ao que tudo indica, esse deslocamento repercutiria em sua ascensão escolar, na medida em que "passaria a ter mais facilidade de estudar morando aqui", assim pôde dar continuidade nos estudos que havia sido interrompido anos antes, quando concluído a educação básica em sua cidade. Dessa forma, em 2000 passou a cursar pedagogia, concluído em 2004, e já no ano seguinte iniciaria uma nova etapa profissional e escolar, caracterizado por sua entrada no mestrado em Educação. Conforme relata em um trecho da entrevista:

Vir para Aracaju foi muito importante e me permitiu avançar em meus estudos, fazer a faculdade no curso de pedagogia, profissionalmente foi muito bom também, porque passei a trabalhar na área que realmente gostava. Pense você que, quando era oficial de justiça, tinha que levar ofícios, intimações para as pessoas, era muito perigoso, já fui até ameaçado de morte, sabe como é essas coisas. Logo que terminei a faculdade, quis dar continuidade nos estudos, foi aí que entrei no mestrado em Educação lá na UFS [...] nessa ocasião já tinha voltado pra Simão Dias. (Entrevistado I) 
Em outro momento, o entrevistado passaria a apontar a importância política de sua vinda para Aracaju, sobretudo, para sua entrada no PV, em suas palavras: "foi nessa época que conheci o pessoal do PV, mas não tinha me filiado ainda, não era o que queria na época". Apesar de ter se inserido em redes profissionais e políticas durante o período em que esteve na capital, sua "raiz" política estaria mesmo em Simão Dias. Ou seja, mesmo morando em Aracaju, seus objetivos políticos só poderiam se concretizar em Simão Dias em função da "ligação política", por isso ele nunca perdia a oportunidade de ir passear em sua cidade natal. Por sinal, o entrevistado relata algo bastante interessante, e que com frequência é destacado pela mídia local, o fato de muitos sergipanos que moram na capital estarem sempre ligados à política das cidades onde nasceram, em algumas cidades, inclusive, o número de eleitores é maior que o de habitantes. $\mathrm{O}$ fato é que, mesmo morando em Aracaju, passaria a disputar eleições em Simão Dias. Essas várias tentativas de acessar o cargo eletivo em sua cidade o levaria a "construção" de um "currículo" extenso de filiações partidárias. Como diz:

Já atuei no PMDB, que no início era MDB, meu avô foi um dos fundadores desse partido, sabe! Disputei três cargos para vereador nesse partido, depois, por questão de existir uma ditadura disfarçada no partido, quer dizer, todos os partidos pregam a democracia, mas tem sempre um grupo que comanda quem vai e quem não vai disputar os cargos. Então, eu saí desse partido, né. Em consequência disso, eu foi pro PHS pra disputar a eleição pra deputado estadual, em 2006, apoiando João Alves Filho e, depois disso, pra disputar a prefeitura, eu fui para o PMN, agora estou no PV, espero poder representar o partido nessa eleição, mas como sabemos o sistema é bruto. (Entrevistado I)

Em outro caso, essa questão também pode ser observada, quer dizer, a migração de um partido para o outro com o objetivo de poder disputar eleições:

Pergunta: O senhor já disputou alguma eleição? Já me candidatei em Rosário do Catete para vereador em 2004, nesse momento eu me candidatei pelo PFL, acho que não consegui êxito por conta de inexperiência política, eu não tinha experiência como candidato mesmo, essa é a verdade. $O$ grupo político que eu estava inserido no momento também não favoreceu, acredito eu que, o principal problema enfrentado foi mesmo por conta do grupo político que não me favoreceu em nada [...] 
Pergunta: $O$ senhor pode dizer como foi sua filiação nesse partido e o que te fez sair? Me filiei em 2003, por conta de alguns amigos lá, ocorre que o PFL era o partido de oposição ao partido do prefeito. Então, assim que me filiei disputei "logo de cara" a eleição de 2004, após o fim desta eleição, em conversa com meus familiares, percebi que fui desfavorecido pelo grupo que controlava o partido na cidade, assim me "desfiliei" do partido [...] foi quando eu fui para o Partido Verde, já fui de imediato. Na verdade, já me filiei com a intenção, a filiação no partido demorou por conta de alguns problemas burocráticos, mas a intenção mesmo era me filiar para poder disputar às próximas eleições representando o partido. (Entrevistado II)

Os dois relatos apresentados acima chamam atenção para a migração partidária entre dirigentes do partido e manifesta, em ambos os casos, o objetivo de disputar eleições e isso pode ser verificado, sobretudo, na fala do Entrevistado II, quando este diz ter entrado no Partido Verde já "na intenção" de se candidatar. Relatos como estes implicam em dizer que a migração entre os dirigentes se dá pela busca de um espaço que lhes permita disputar cargos eletivos. Assim, sempre que surgir algum entrave a tal objetivo, não hesitam em se "desfiliar" e filiar em outro partido.

Segundo o Entrevistado II, após ter saído do PMN (Partido da Mobilização Nacional) não teria entrado direto no PV, ocorre que, ele havia dado "entrada nos papéis" necessários para instituir um novo partido no Estado, o PN (Partido Nacional), chegando ir à Brasília estabelecer as relações e os contatos necessários. A instituição desse novo partido, segundo ele, garantiria a possibilidade de dominar as "regras" e o "jogo" interno, de modo que pudesse se promover e disputar eleições "quando bem quisesse". Foi nesta mesma ocasião que procurou o então presidente do PV, na época Carlos Pinna Júnior, o qual conhecera durante o período em que morou em Aracaju, quando ambos trabalhavam em uma faculdade particular da cidade.

Tais contatos, favorecidos pela ocupação profissional, permitiam-lhe uma primeira aproximação com o PV. Assim, diante das imposições acerca da formação de um partido político, o PN, o dirigente em questão procuraria Carlos Pinna Júnior novamente, objetivando desta vez a possibilidade de fundar o diretório municipal tal como lhe havia sido oferecido em outra ocasião. Tanto o presidente do partido quanto outros membros aceitaram essa oportunidade e deram "carta branca" para formar tal diretório em Simão Dias. Nesta cidade, o entrevistado em questão seria designado como presidente municipal, tendo obrigatoriamente que recrutar outros membros para formar o contingente 
necessário. Isso ocorreu em 2007, mesmo ano em que ele seria mais uma vez convocado pelo presidente do partido para uma conversa em que lhe seria oferecido "um posto na estadual", que foi aceito prontamente, passaria a ocupar também a função de secretário de formação do PV estadual.

Os efeitos dessa relação com o PV foram sentidos na cidade onde mora, pois, por ser uma cidade relativamente pequena, todos passariam a ter conhecimento de tal filiação, bem como de suas pretensões futuras de se candidatar enquanto representante da agremiação no município. É pertinente destacar que, dado o fato de se tratar de uma cidade pequena, onde o espaço político é reduzido, onde poucos podem ter acesso à disputas eletivas, o fato de poder disputar eleições já pode ser o diferencial, pois, não raro, grande parcela dos que pleiteiam tal participação são excluídos do "jogo" pelos "selecionadores" antes mesmo de se filiarem em partidos políticos. Ou seja, em se tratando da trajetória política do Entrevistado I, o acionamento dos laços familiares e das capacidades adquiridas pelo convívio com seu avô poderia lhe trazer vantagens, de modo que o reconhecimento social desta "herança" seria convertido em "trunfo" político, na medida em que o voto deixaria de ser individual, tornando-se um voto de adesão a facções políticas distintas. (CANEDO, 2002; 2005; PALMEIRA, 1996) Porém, como visto ao longo do texto, às disputas internas por conta de quem pode se apresentar como "herdeiro" do seu "Raimundinho" acabou prejudicando os anseios políticos do entrevistado em questão, na medida em que o "reconhecimento" da "herança" política de seu avô ficaria mesmo nas mãos de seu tio. Em virtude disso, ainda que seja possível se filiar a outros partidos como o fez sempre - a indicação como representante destes para disputar eleições dificilmente ocorreria. Neste sentido, se engajar no PV e ascender hierarquicamente neste partido lhe permitiu dominar o "jogo" dos "selecionadores", passando a disputar, desde então, campanhas políticas no município ou mesmo à nível estadual como o fez em 2010 quando concorreu para deputado estadual.

Essa modalidade de engajamento permite mostrar a importância do partido frente às necessidades dos "dirigentes-políticos", quer dizer, de agentes que se filiam em partidos políticos objetivando exclusivamente disputar eleições. As relações estabelecidas a partir da posição ocupada por esses permitem uma atuação mais eficaz no meio político, pois na qualidade de dirigente de um partido podem acessar tanto o reconhecimento social de uma "gramática de ação" própria, quanto a oportunidade de estar concorrendo a cargos eletivos, na medida em que, mediante a posição ocupada no partido, passa-se a ser um "selecionador" 
e não mais um "selecionável". Ou seja, nesta perspectiva, segundo Gaxie (1977), o partido funcionaria como uma "empresa" comprometida com a conquista do poder político de suas lideranças.

Todavia, há alguns perigos em categorizar os líderes considerados nessa pesquisa desta forma, pois se, num primeiro ponto, às ideias lançadas nesse tópico parecem mesmo encontrar embasamento, na medida em que um grupo de dirigentes encontra no partido meios para se inserir em disputas eletivas, por conseguinte, essa conduta analítica não aborda todas as variáveis que podem estar por trás dos motivos pelos quais os agentes se engajam em um partido. Ao contrário disso, essa visão levantada no trabalho de um "dirigentes-políticos" dá a impressão que lidamos com um universo empírico extremamente politizado, e não foi o que demonstramos ao longo do texto. Isto é, se foram encontrados dirigentes com essas características, também surgem outros padrões de engajamento que merecem ser destacados.

\section{PADRÃO 2: POLÍTICOS POR "FORMAÇÃO" - EXCELÊNCIA PROFIS- SIONAL E RECRUTAMENTO DE LÍDERES DO PV}

Enquanto na modalidade anterior mostrou-se que o engajamento de lideranças partidárias pode ser também resultado de um investimento político, e a partir dele o dirigente passaria a ter maiores chances de disputar eleições assim como um maior domínio simbólico do eleitorado do partido, a modalidade ora apresentada objetiva avaliar em que medida às categorias profissionais compõe as bases de recursos dos que "chegam" aos postos de comando no partido e como essas categorias se combinam com outros recursos (adquiridos ou herdados) ao longo do trajeto social. Para isso, dois grandes padrões foram marcantes entre os entrevistados: 1) em uma primeira modalidade encontramos os que combinam recursos escolares, profissionais e econômicos como fator de recrutamento no partido; 2) já em uma segunda modalidade, observamos agentes que combinam o engajamento no partido com inserção de redes de relação que possibilita a reconversão de recursos profissionais em ocupação de postos profissionais para além do espaço do partido. Esses padrões servem de base para visualizar um dos principais timos de reconversão encontrado entre os agentes investigados ao longo da pesquisa. 


\section{PADRÃO 2.1: RECURSOS SOCIAIS E PROFISSIONAIS -O RECRUTA- MENTO FEITO “DE CIMA"}

O presente tópico representa o padrão de associação e reconversão característica daqueles que fizeram carreira profissional ascendente, tornando-se profissionais reconhecidos no "mercado" ao mesmo passo em que essa carreira profissional lhes permite um "bom" acúmulo de recursos econômicos e a inserção em espaços de "poder". Esse perfil de dirigente é fundamental para a ascensão do partido dentro da conjuntura política local. Permite, entre outras coisas, a "promoção" do partido antes e durante o "tempo da política", não raro, se tornam o "homem de frente" do partido, aquele que vai à mídia, negocia alianças com líderes de outros partidos, já que os conhece e também é reconhecido, busca apoio econômico nas "altas rodas" e, além disso, eleva o partido à condição de igualdade frente às disputas eleitorais.

O caso a ser apresentado é o de um dirigente, atualmente com 72 anos de idade. Filho de militar da marinha e de mãe dona de casa, natural de Ceará-Mirim, Rio Grande do Norte, vivenciou em sua infância algumas das consequências da Segunda Guerra Mundial, uma das lembranças mais marcantes de sua infância é o fato de não poder "acender as luzes à noite", ocorre que Natal-RN se tornaria, naquela época, uma das bases militares dos EUA e um possível alvo das tropas nazistas. Outro fato que marcaria sua infância naquele estado também está relacionado à Segunda Guerra Mundial. Ocorre que seu pai, militar da marinha, havia sido convocado para a guerra, mas, como moravam no interior, em uma chácara onde não havia qualquer meio de comunicação, seu pai não foi informado. Quando retornou ao serviço militar meses depois foi imediatamente preso. $O$ entrevistado relata que nesta ocasião estavam sua mãe, irmãos e ele, a esperarem fora do quartel, quando um oficial veio comunicar-lhes do ocorrido. Preso, seu pai foi julgado e condenado pela corte marcial a um ano e meio no quartel. Esse episódio causaria em sua família uma grande perda financeira, uma vez que seu pai era o único responsável pelo provimento do lar. Ainda, segundo relato, tal episódio de "injustiça" seria também decisivo para o desenvolvimento de seu principal objetivo profissional, qual seja o de se tornar advogado, pois "não queria que algo desse tipo acontecesse com outros pais de família".

Trata-se da trajetória do Entrevistado II. Depois de ocorrido o episódio com seu pai, a família resolveu mudar de cidade indo morar, no início da década da década de 1950, no Rio de Janeiro. Nesta cidade viveria boa parte de sua infância e início da adolescência. Por incentivo de seu pai, se dedicou aos estudos, 
tendo sido um bom aluno. Apesar de seu pai não ter concluído o segundo grau, relata que se tratava de um homem culto e "de uma sabedoria incrível", sempre acompanhava seus estudos e de seu irmão e irmã. No Rio de Janeiro passou a estudar em um colégio interno, bastante exigente, por sinal. Lembra de episódios onde era severamente castigado por qualquer que fosse o "desvio de conduta". O fato é que ele teve em sua escola uma professora, dona Maria Josefa, que se tornou uma boa amiga, que lhe ajudara em momentos difíceis e que conversava com ele e seus colegas sobre política e sobre "coisas da vida". Segundo o entrevistado, esse teria sido os primeiros contatos com a política, já que em casa "não se falava no assunto". Por conta disso, atribui a sua passagem pela educação básica uma referência que lhe causaria o desenvolvimento do "gosto" pela política.

Eu vejo que a escola tem um papel importante, quer dizer, a escola ministra o conhecimento, mas deve saber que seu principal papel é educar pra vida [...] me recordo, aliás, que em 1950, eu era aluno da escola primária, isso lá no Rio de Janeiro, estava tendo eleições para presidente, eu entrei correndo na sala com a foto de Getúlio Vargas dizendo pra professora "olha o velhinho, vote no velhinho" foi quando ela se voltou pra mim e disse: "eleição é uma coisa séria, devemos levar à sério aquilo que traz tantas consequências na vida da gente". Desde então passei a ver a política como uma coisa séria e que deve igualmente ser levado à sério. (Entrevistado II)

A esse respeito, a literatura sociológica tem demonstrado uma ligação entre a formação básica (universo escolar) e a aquisição de competências políticas. (GAXIE, 1978) Aos 16 anos de idade, agora já morando na Bahia, seu pai o matriculou em outro colégio interno, como diz em sua fala, a formação rígida foi uma marca de sua vida escolar, seja por parte da escola ou das cobranças de seu pai. $O$ fato é que nessa escola passaria a se envolver mais com a política estudantil, relata que quando era seminarista passou a participar de campeonatos de oratória no colégio, sendo campeão por duas vezes. $O$ que lhe inseriu no universo político da escola onde estudava, foi também, nesta mesma época, o fato de ter sido eleito presidente do grêmio estudantil, chegando a ocupar posteriormente o posto de diretor de Cultura da Associação baiana de Estudantes Secundaristas. Isso o levaria a participar de passeatas de apoio aos estudantes e de protestos pela rua, em uma ocasião conta que conseguiu reunir mais de cinco mil pessoas em uma única passeata. Um fato que chama atenção em seu relato é que, ao contrário de boa parte dos estudantes da época, ele se manifestava contra os "comunistas", porém, por muitas vezes tivera que "camuflar" esse 
ponto de vista político-ideológico e atribui tais valores a sua formação rígida e sua ligação familiar com o militarismo. Seu envolvimento no grêmio estudantil teria sido seu último envolvimento militante-associativo.

Terminado a educação básica em fins dos anos de 1950, conseguiu entrar logo em seguida no curso superior. Tal como havia prometido a seu pai, no início dos anos 1960 iniciou o curso de direito pela Universidade Federal da Bahia (UFBA). O comprometimento demonstrado na educação básica foi também observado na carreira acadêmica, fato que lhe rendeu a oportunidade de advogar "mesmo antes de se formar". Segundo ele, a "boa" formação que estava tendo e as oportunidades que lhe surgiam por morar em uma cidade pequena permitiram essa possibilidade. Como diz: "na cidade que morava havia só três advogados, então fui chamado para ser advogado, antes mesmo de me formar". Logo que terminou o curso superior fez concurso para o Procurador da República, tendo sido aprovado em primeiro lugar, ocorre que, em um dos pontos do edital especificava que deveria ter no mínimo cinco anos de experiência para poder assumir o cargo. Desse modo, quando foi apresentar os documentos necessários, foi-lhe questionado como ele, tendo apenas um ano de formado, poderia estar preenchendo tal requisito. Após comprovar os "serviços prestados" como advogado em sua cidade, sua aprovação foi deferida, passando a trabalhar como Procurador da República, emprego este que lhe traria uma considerável ascensão econômica. Como Procurador da República foi designado para trabalhar em São Paulo, lá iniciaria mais uma etapa de seu itinerário acadêmico. Logo que chegou na cidade, se matriculou no mestrado em Direito Criminalista pela Universidade de São Paulo (USP).

Sua carreira profissional seria o meio que o traria para Aracaju, como diz: "vim para Aracaju para substituir um procurador da república, amigo meu, nesta ocasião vim pra ficar apenas 60 dias, mas me apaixonei pela cidade de modo que nunca mais sai daqui". Assim, consegue transferência para trabalhar em Aracaju. Iniciando uma carreira profissional ascendente e que, em alguns momentos o levaria a inserção na política, passando a nutrir um "sonho de ser constituinte".

Quando chegou à Aracaju, em pleno auge da ditadura militar, passou a militar no Movimento Democrático Brasileiro (MDB). Nesse partido teria ganhado projeção e disputado algumas eleições. Essa projeção no partido e na política local tornou-se mais acentuada quando, em uma ocasião teria participado de um famoso caso jurídico do Estado, pois defendeu "Chico de Miguel", ${ }^{10} \mathrm{em}$

10 Esse é um dos mais famosos casos de crime político do Estado. O comerciante Francisco Teles de Mendonça, também conhecido na região como "Chico de Miguel", era um importante cabo eleitoral do 
função disso, ganharia ali um importante aliado político e, além disso, projeção profissional, pois sua "vitória em uma derrota quase certa" lhe fez se tornar um advogado famoso no Estado. Segundo seu relato:

Meu partido na época, o MDB, eu tinha feito um júri aqui no Estado, famoso, defendi "Chico de Miguel", quando acabou o julgamento, ele me chamou e disse como eu não tinha cobrado nada ia me ajudar a ser eleito. Segundo ele eu seria com certeza eleito senador na próxima campanha. Mesmo com sua ajuda, o MDB tinha feito alguns acordos e resolveram me 'segurar' um pouco, para que eu pudesse me candidatar à deputado. Nessa ocasião eu disse que não tinha condições na época, e o partido disse que ia me ajudar, bom eu confiei, né. Mas, pra você ter uma ideia, no decorrer da campanha o MDB me deu cinco mil cartazes para a campanha à deputado, enquanto um candidato para vereador gastava cerca de cinquenta mil cartazes em Aracaju. Quer dizer, fui candidato com a derrota certa. Esta seria uma boa oportunidade de assumir um posto legislativo estadual, mas infelizmente, a oportunidade fugiu de minhas mãos. Não culpo o "Chico" por isso, ele fez a parte dele, era um homem de palavra, mas tem coisas que não estavam em suas mãos. (Entrevistado II)

O fato é que em Aracaju ele conseguiu construir uma carreira jurídica e política sólida. Em 1978, durante o governo de Augusto Franco, assumiu o posto de Secretário do Estado da Administração, tendo permanecido nessa função por onze meses. Como diz: "Augusto queria me eleger deputado, mas me pedia que eu nada falasse, nada fizesse, precisava naquela época de um homem com sabedoria suficiente para guiar os 'burros"', se referindo ao grupo que lhe cercava. Durante o governo de Valadares foi nomeado secretário do Estado, "ele criou a secretária de Estado para Assuntos Parlamentares”. Em função desta ligação com Valadares, teria sido um dos juristas escolhidos para escrever o anteprojeto da Constituição do Estado de Sergipe, como diz: "entreguei a ele e ele entregou à assembleia legislativa".

udenista Euclides Paes Mendonça, quando este e seu filho foram assassinados, fato este ocorrido em agosto de 1963. Ocorre que, uma conhecida "rixa" comercial e política entre Euclides e Manuel Francisco Teles (Partido Social Democrático - PSD), teria sido os motivos do assassinato. Esse duplo assassinado incomodaria os udenistas de Itabaiana por cerca de quatro anos, agora sob o comando de "Chico de Miguel". Em 1967, Manuel Teles foi assassinado por um pistoleiro conhecido como Antônio Letreiro, sem demora "Chico de Miguel" foi acusado de ter sido o mandante do assassinato, fato que levou a cassação de seu mandato de Deputado. Além de ter sido preso pelo exército que o entregou à justiça comum. "Levado a júri, depois de mais de três anos de cadeia, foi absolvido". As informações sobre a história de "Chico de Miguel" foram colhidas no texto de Mendonça (2011). 
Em 1988, foi também indicado para a vaga de Diretor Jurídico e, depois, para Diretor Administrativo, ambos na Assembleia Legislativa. Segundo ele, dois convites inusitados. $O$ primeiro foi feito por Antônio Passos, quando este foi pessoalmente em sua casa e disse que havia assumido a presidência da assembleia e que precisava de alguém no departamento jurídico. Como diz: "bom, ele chegou em minha casa e disse pra mim eu quero alguém no departamento jurídico, alguém que eu confie". O segundo cargo citado foi por convite de Antônio Carlos Franco, permanecendo nesse cargo por um ano e meio. Esse conjunto de cargos não eletivos demonstra a influência e sua circulação nas "altas rodas" políticas do Estado. Sendo possível dizer que, tais contatos, favorecidos pela função profissional e política, permitiram-lhe a possibilidade de se eleger vereador de Aracaju. Fato este alcançado na eleição de 1992, quando estava filiado no Partido Democrático Trabalhista (PDT).

Porém, ter sido eleito vereador o levaria a um "desapontamento" com o "poder", ocorre que, nos quatro anos em que esteve na Câmara dos Vereadores não conseguiu aprovar nenhum projeto, nenhuma lei. Percebeu que os "conchavos existentes no meio político impedem de um bom desenvolvimento daqueles que tem 'boa' vontade". De todo modo, não viu este como um "bom" momento de sua vida, percebeu, na prática, que não teria "nascido para isso", como diz: "não sou demagogo o suficiente, não sou falso, não sei agradar ou beijar no rosto das pessoas só pra ganhar voto". Em função disso, depois de terminado seu mandato, resolveu não se candidatar novamente. Para não sair de vez da política, mudou de partido, passando a militar no Partido do Movimento Democrático Brasileiro (PMDB), seria uma espécie de retorno ao $\mathrm{MDB}$, partido que teria marcado sua vinda para Aracaju, todavia, desta vez, sua filiação não duraria muito, pois entraria em desavenças com o "grupo dos Franco", grupo que comandava o partido no Estado.

Depois dessas desavenças políticas com membros do grupo Franco, eu fiquei um pouco sumido do cenário político local, pra você ter uma ideia eu dava entrevistas todos os dias, e depois disso fiquei sete anos sem sequer ser procurado por repórter nenhum, bom, você sabe quem controla a mídia local, né? Então aí já explica os motivos desse 'anonimato'. Isso só mudou quando peguei um caso de repercussão nacional, e foram me procurar para me entrevistar, eu poderia, naquele momento dizer que não dava entrevista, mas fiz diferente, respondi tudo que me perguntaram. (Entrevistado II) 
É pertinente destacar que sua carreira política esteve sempre relacionada à sua carreira jurídica, de modo que uma não estava dissociada da outra. $\mathrm{Na}$ verdade, sua atividade profissional lhe permitiu a inserção no universo político, frequentar lugares, desenvolver amizade com pessoas influentes da política local, como por exemplo, membros da família Franco, do grupo de João Alves Filho, entre outros. Dado o fato de ser um dos advogados mais conhecidos da região e sócio majoritário de um dos principais escritórios jurídicos do Estado, que também leva seu nome, seu reconhecimento social e profissional o levaria a ocupação de mais um posto profissional, pois iniciaria sua carreira na área da educação.

Para ilustrar o reconhecimento profissional do dirigente em questão, cita-se duas reportagens disponíveis em jornais eletrônicos da região:

“[...] O advogado criminalista XXX esteve na tarde desta segunda-feira (16) no presídio Jacinto Filho, bairro Santa Maria, em Aracaju (SE), por temer que atentassem contra a vida do seu cliente, Fábio Calheiros, interno do complexo penitenciário desde o dia 10 de abril de 2011. Fábio é filho do empresário Floro Calheiros Barbosa, morto no ano passado numa operação policial. XXX informou que a rebelião já era anunciada, como também anuncia outras rebeliões em outros presídios de Sergipe e destacou que continua temendo pela vida de Fábio Calheiros. "Vocês todos sabem, não é segredo que de 20 a 28 de março, eu anunciei a Sergipe que Floro, Fábio e Lucas morreriam antes que abril terminasse. Eu pergunto a você: Morreu quantos? Claro que numa rebelião alguém quisesse se aproveitar da confusão e satisfizesse interesses primitivos, que felizmente são acalentados pela alma humana [...]".

"[...] Não vou defender quem foge. Até mesmo porque iria misturar o emocional com o racional. Foi o que afirmou o conhecido advogado criminalista $[\ldots . .]^{11}$

Como dito, o entrevistado em questão também passaria a trabalhar no meio educacional, tornando-se professor universitário, lecionando disciplinas relacionadas ao seu espaço de trabalho. Portanto, passaria a combinar em suas aulas competências adquiridas na academia (com sua pós-graduação, por exemplo) e os saberes adquiridos com a vivência de mais de 44 anos como advogado criminalista, vivenciando na prática todas as nuances de um tribunal

11 Informações disponíveis em: EVALDO. Campos não quer nome associado ao do sogro. Infonet, Aracaju, 23 nov. 2009. Disponível em: https://infonet.com.br/noticias/cidade/evaldo-campos-nao-quer-nomeassociado-ao-do-sogro. Acesso em: 14 ago. 2013. 
do júri. Por essa inserção também na profissão de professor universitário, não raro, se apresenta como jurista e professor. Acrescenta-se ainda que sua inserção na carreira acadêmica passaria a ocorrer em simultâneo com a atividade de jurista. Por falar nisso, seu retorno à atividade política tem muito a ver com essa segunda profissão, pois ministra aula de ciência política e relata que, em uma ocasião, um de seus alunos o teria indagado sobre qual partido estava filiado, o que o levaria a refletir sobre sua posição em relação à política e passaria a pensar em seu retorno. Segundo ele:

[...] foram meus alunos, meus alunos de ciência política. Eu cobrava deles participação na vida pública. Lembro que um dia, um aluno meu me perguntou qual partido eu estava filiado, eu respondi que em nenhum, ele sem demora respondeu-me: então que autoridades têm de nos cobrar filiação partidária. Chegando em casa, procurei minha mulher e falei o acontecido, ela disse então por que não procura um partido. Confesso que este momento voltei a pensar em voltar para a política, mas aquela lembrança ainda me perseguia [...] (Entrevistado II)

O relato acima permite avaliar a importância que sua carreira como professor têm sobre sua volta à política. Passaria, por um bom tempo, a pensar em tal possibilidade, porém, não via "um partido que pudesse lhe trazer tal oportunidade", quer dizer, oportunidade de se "envolver em um ideal, defender uma bandeira", mas sem necessariamente ter de disputar cargo eletivo. Essa questão implica em uma questão bastante importante a respeito do ponto de vista do agente sobre sua vida política. Se a experiência como legislador não tinha sido de grande importância para sua vida, suas atribuições burocráticas assumidas em função de seu conhecimento político lhe trazem certo orgulho. Durante a entrevista e em conversas não formais, demonstrava o quão importante foi pra ele se envolver daquele modo com a política, como diz: "ser chamado pra trabalhar em cargos burocráticos como trabalhei era uma forma deles me dizerem assim olha, você é um excelente profissional, é o melhor e por isso quero você ao meu lado". Em consequência desse conjunto de relações proporcionadas por sua carreira política e profissional ascendente, é possível dizer que estamos lidando com um agente dotado de prestígio social, o que lhe permite o reconhecimento entre o meio político do Estado e, mais tarde, a aproximação com o pessoal do PV, sobretudo o desenvolvimento de uma amizade com o então pre- 
sidente (Entrevistado V) ${ }^{12}$ do partido. Fato este que, conforme já demonstrado em outro momento, o agente em questão passaria a ser sondado por lideranças do partido, no sentido de se filiar ao mesmo, até que em 2008, em face de uma constante insistência, filiou-se ao PV.

[...] me pediu, eu não tenho tempo, mas não poderia negar essa ajuda no partido. Até por que, não é vaidade não, mas eu tenho nome que merece respeito na sociedade, claro que eu não vou contentar a todos, então meu nome ajuda o PV, e se ajuda o PV eu acho que não posso negar. Eu não tenho atribuições no partido que não entrem em conflito com minhas posições profissionais. Embora eu seja um homem ocupado, dá pra conciliar trabalho com a participação no partido, ir às reuniões, participar dos debates e, se tiver campanha de algum candidato do partido eu vou apoiar o partido. (Entrevistado II)

O último partido que estive filiado antes do PV foi o PMDB, na verdade, eu saí por que queria sair de tudo, eu só sei disso, eu não queria mais me envolver com a política [...] E aí eu pensei, onde? Busquei um partido que tinha compromisso com a natureza, com a sustentabilidade, um partido que sequer ia me exigir sequer disputas eleitorais. Quando procurei fui questionado por outros membros do partido se eu estava me filiando para ser candidato, então respondi que seria apenas ser mais um "soldado" do partido. (Entrevistado II)

Debater esse caso em particular nos permite perceber a compilação de diversos fatores sobre os pontos de chegada aos postos de liderança no PV. Diferente de vários outros líderes desse partido, o entrevistado em questão possui o que podemos chamar de capital político, acumulado ao longo de sua vida através da ocupação de cargos públicos e eletivos. Já tendo feito parte de grêmios estudantis eocupado cargo comissionado na secretaria municipal, bem como o cargo de vereador da capital.

Apesar disso, atribuir o recrutamento só às condições politicamente acessíveis reduziria os motivos a uma única variável. Chama atenção também o reconhecimento profissional e social que o Entrevistado II detém. Esse reconhecimento lhe proporcionou ao longo de sua trajetória político-profissional um considerável prestígio social.

12 Trata-se de um homem de 52 anos com Ensino Superior Completo (Engenharia Civil) e servidor concursado do Fisco Estadual. A entrevista foi realizada em março de 2012. 
Considerando que as posições políticas resultam da associação entre recursos profissionais e sociais, é possível dizer que neste caso lidamos com um exemplo em que a compilação de diferentes recursos (social e político), somados a uma trajetória profissional ascendente - representado aqui pela carreira de jurista, de professor universitário e de burocrata do Estado - nos permite entender o lugar que esse entrevistado ocupa dentro do partido. Isto é, tanto a trajetória social e profissional quanto o capital político detido por esse agente permitem entender o convite a fazer parte do partido, bem como a oportunidade de ocupar o posto de vice-presidente assim que se filiou.

O fato é que o padrão de recrutamento demonstrado nessas linhas eleva o partido e permite aos membros uma projeção no espaço político local. Sobre essa questão, o fato desse agente possuir um capital social elevado o torna sempre uma referência externa do partido. Nas eleições para prefeito de 2012, o partido não se coligou com nenhum outro, entrou com "chapa" própria, o entrevistado em questão foi indicado à vice-prefeito e o candidato à prefeito foi o então presidente do partido. (Entrevistado V) Mesmo se tratando de um partido sem muita influência dentro do "jogo" político do Estado, observa-se que as posições de poder do qual o partido dispõe para suas lideranças são reservadas para membros que podem também estar trazendo "vantagens" para o partido.

\section{PADRÃO 2.2: INSERÇÃO PROFISSIONAL E ENGAJAMENTO DE LIDE- RANÇAS NO PV}

Enquanto no tópico anterior os esforços foram feitos no sentido de demonstrar como os recursos profissionais criam condições de recrutamento dos líderes do PV, nesta modalidade pretende-se discutir outra variável do recrutamento, feito a partir de categorias profissionais. Ocorre que, conforme foi observado, o fato de engajar-se no PV também pode provocar uma ampliação das redes (sociais, profissionais) de relações. Em se tratando do viés eminentemente profissional dos líderes, notamos um padrão de recrutamento relacionado à inserção profissional e às influências do engajamento sobre a inserção profissional de determinados líderes. Como pressuposto, é pertinente destacar que a conquista de cargos e o acesso a benefícios materiais, bem como a recompensas simbólicas (prestígio, poder, honra), podem ser acessadas a partir das posições ocupadas pelas lideranças partidárias. (GAXIE, 1977)

O caso a ser descrito é o do dirigente (Entrevistado VII), nascido em Brasília - DF, em 1981, que ainda muito cedo teria vindo morar com seus pais em 
Aracaju. De origem social elevada, a relação com a política marcaria a trajetória ascendente de sua família e estaria sempre relacionada a conquistas profissionais. Seu avô materno já ocupou o posto de deputado federal entre as décadas de 1970 e 1980, fator que o levaria a morar em Brasília. Nesta ocasião, sua mãe, já adolescente, teria passado no vestibular e entrado no curso de Pedagogia pela Universidade de Brasília (UNB), onde mais tarde conheceria seu futuro esposo, que cursava Economia na mesma universidade. Com ele casou-se e tivera três filhos, entre eles o líder em questão, seu filho mais velho. Assim, é possível dizer que ele teria crescido em um ambiente relativamente favorável à atividade cultural e política, manifestada, por um lado, pela carreira política de seu avô e, por outro, pela formação superior de seus genitores.

Neto do ex-deputado federal Tertuliano Azevedo, que foi eleito nas eleições de 1978, antes mesmo de nascer "já estava na política", ocorre que, em função da posição política de seu avô, toda sua família teria ido morar na capital federal. Acontecimento este que marcaria a trajetória do grupo familiar e repercutiria sobre o itinerário escolar e profissional de seus membros. $O$ fato é que, neste ambiente, caracterizado por um nível social relativamente elevado em função das atribuições profissionais de seu avô, o líder em questão pôde estar sempre "envolto do poder", pois, apesar da "aposentadoria" política de seu avô, este ainda nutri "velhas amizades", as quais lhe renderiam "favores" políticos e profissionais por bastante tempo.

Quando terminado o mandato, seu Tertuliano retornaria para Aracaju, porém, sua filha continuaria morando em Brasília, pois já casada e ainda terminando o curso superior de pedagogia ficaria impossibilitada de retornar com seu pai. No ano seguinte, já concluído o curso superior, ela teria feito um concurso para a área em que se formou, mas não chegaria a exercer a profissão. Acontece que seu Tertuliano tinha "alguns amigos aqui em Aracaju" e, também, "por estar com saudade de sua filha e netos" consegue transferi-la para Aracaju, além de "arranjar um emprego no Tribunal de Contas" para seu marido. Dessa forma, a mãe e o pai do entrevistado vieram morar na capital sergipana. Ficariam nesta cidade por alguns anos, pelo menos até nosso entrevistado completar 14 anos, quando voltaram para Brasília, onde sua genitora passaria a ocupar um cargo no Senado federal. Nas palavras do entrevistado "lá ela trabalhou no $\mathrm{RH}$, depois para o departamento médico, onde trabalha até hoje". Seu pai também assumiria cargo de comissão no governo, "lá em Brasília começou no Ministério do Planejamento, depois quando veio para Aracaju passou a trabalhar no Tribunal de Contas e quando retornou ocupou seu antigo posto no Ministério do Planejamento", onde esta as vésperas da aposentadoria. 
Ao que tudo indica, o retorno de sua família para Brasília marcaria sua vida, no sentido de lhe inserir em ambientes onde a proximidade com a política passaria a ser constante, se inserindo, por assim dizer, em redes de relações favoráveis ao envolvimento político-associativo. Em função de sua mudança para a capital federal, passaria sua infância e adolescência longe de seu avô materno, uma importante referência política para ele e sua família. Todavia, pontualmente, seu avô ia para Brasília passear e matar a saudade da filha e dos netos. Nessas ocasiões, o entrevistado passaria a acompanhar seu avô "em encontros com 'antigos amigos", adquirindo assim toda uma "gramática política" simultaneamente com uma inserção em redes de relações favoráveis a seu itinerário profissional e político. $O$ fato é que seu avô era uma referência para ele, de modo que passaria a seguir seus passos, inclusive, tornando-se bacharel em direito, tal como seu progenitor.

Em uma das ocasiões em que seu avô foi passear em Brasília, levou-o para conhecer um amigo que era, na época, deputado federal, deixando aos cuidados deste amigo o "currículo" de seu neto. Conta que, passando-se alguns meses, quando já estava "sem esperanças de ser chamado", toca o telefone, era esse amigo de seu avô convidando-o para trabalhar no Congresso Federal. Conforme relata:

[...] meu avô sempre que ia nos visitar me levava ao congresso nacional, ele podia entrar lá, tinha alguns amigos ainda daquela época que foi deputado, uma vez eu "tava" trabalhando em um escritório imobiliário, já fazia direito já, ai ele me pediu que eu fizesse um currículo que ele daria um jeito, então ele me levou junto com ele, procurou um amigo seu aqui de Sergipe, e falou sobre mim e deixou meu currículo, mas assim, eu não tinha aquela coisa assim, bom eu não esperava, é que eu vejo um interesse muito forte na política, sabe, e como meu avô já fazia tempo que não estava envolvido com esse pessoal, não esperava mesmo que fosse chamado para o cargo, mas passado um tempo, acho que mais ou menos uns quatro meses, toca meu telefone, fiquei meio sem acreditar, mas deu certo, fui chamado para ocupar um cargo de liderança no partido, era na época o PFL, hoje DEM, na verdade. Eu não fiquei ligado a nenhum deputado, prestava serviço pro partido [...] fiquei lá por quatro anos, só sai mesmo por que eu quis, queria vir pra Aracaju [...]. (Entrevistado VI)

O trecho apresentado acima ajuda a entender os contornos que conduziram o líder em questão ao seu primeiro cargo de confiança. À exemplo de sua 
mãe, os conhecimentos de seu avô permitiram-lhe a inserção em postos burocráticos do Estado. Nessa ocasião, suas atribuições profissionais estavam ligadas ao Partido da Frente Liberal (PFL) - atual Democratas (DEM) -, em que teria como tarefa a assessoria legislativa, mas, como diz, não estava subordinado a nenhum deputado específico, prestava serviços para todos os deputados da legenda. Por falar nisso, apesar de ter permanecido nesta função que estava ligada ao PFL, o entrevistado não se filiaria a esse partido, sendo que sua primeira filiação seria no PV.

Em 2006, esse líder pediria demissão do seu cargo no Congresso Nacional, essa demissão estava relacionada a um antigo desejo de voltar para Aracaju e, nesse momento, já formado bacharel em direito, teria a grande chance de alavancar sua carreira profissional. $O$ fato preponderante para sua decisão foi alguns contatos feitos entre ele e um amigo seu de infância, que havia morado no mesmo prédio que ele durante o tempo em que morou em Aracaju. Tais contatos se tornaram mais frequente em função da possibilidade desse seu amigo "arranjar" alguma coisa para ele: trata-se do também advogado Carlos Pinna Júnior, na época presidente do PV. Ocorre que Pinna Júnior é filho de Carlos Pinna de Assis, presidente do Tribunal de Contas do Estado de Sergipe, e quando seu pai assumiu esse posto Pinna Junior passou a oferecer a oportunidade do entrevistado vir para Aracaju e trabalhar no Tribunal de Contas.

Assim que chegou à cidade já iniciaria seu trabalho no Tribunal de Contas, lá assumiria a função de assessor jurídico, portanto "passaria a exercer a função que havia me formado para exercer". Além das atribuições profissionais conquistadas neste espaço, também passaria a manter contato diário com Pinna Junior, que se tornaria seu colega de trabalho. Certamente, o contato diário com esse agente seria a explicação de sua entrada no PV, pois era constantemente sondado sobre tal possibilidade, até que, ainda em 2006, se filiaria ao PV. Nesse mesmo ano, seria também designado como Secretário da Juventude do partido, função que exerce até hoje.

Os dois casos apresentados representam uma modalidade de engajamento cuja base principal vem das relações profissionais e, como visto, do acionamento de redes de relações que permitem a conversão desse recurso em posição no interior do partido. Como visto, embora esse recurso tenha se mostrado eficiente, conjuga-se que tais recursos servem como justificativa dos "postos de chegada". Em relação às categorias profissionais, observamos na trajetória dos dois agentes apresentados duas modalidades de reconversão. No primeiro caso apresentado, observamos que a carreira profissional ascendente inseriria o agente em questão em espaços que potencializara seu capital social e político 
de modo que sua carreira política e profissional passaria a se tornar um "trunfo" para o partido, na medida em que se tornaria uma das principais lideranças do partido no Estado, representando o partido em disputas eletivas e também frente à mídia. No segundo caso apresentado, observamos que mesmo se tratando de um engajamento por vias profissionais, o recrutamento está mais relacionado à uma estratégia do agente em questão de iniciar sua carreira profissional, neste caso, o engajamento representa a possibilidade de ascensão profissional e também a manutenção das relações que esse inseriu no "mercado".

A comparação entre as duas trajetórias sociais permite avaliar por que esses líderes obtiveram rendimentos desiguais dos mesmos recursos. (BOURDIEU, 1998) A esse respeito, conforme argumenta Gaxie (1977), a probabilidade de líderes partidários converterem às posições que ocupam dentro do partido em posições profissionais depende, de um lado, da posição hierárquica que ocupa no partido e, por outro lado, da posição social que o mesmo ocupa e da estrutura de recursos sociais dos quais ele dispõe. Então, a posição ocupada no partido reflete, por um lado, às estruturas sociais das quais esses agentes advêm e, por outro lado, às retribuições materiais que o partido pode trazer aos seus dirigentes depende da posição social que esses ocupam.

\section{CONSIDERAÇÕES FINAIS}

O presente trabalho teve por objetivo compreender o líder partidário enquanto sujeito imerso numa rede de relações estabelecida ao longo de sua vida. Esse assunto trouxe como implicação considerar uma dupla assertiva: a primeira, que determinantes sociais exercem força sobre a chegada aos postos de liderança disponíveis no partido, e a segunda, que a ocupação destas posições permite com que esses líderes se insiram em espaços favoráveis a sua ascensão política e social. Ou seja, a dificuldade principal desse estudo pousou sobre a necessidade de ter de considerar o líder enquanto um sujeito imerso num conjunto de situações e em trânsito constante em diferentes espaços.

Para operacionalizar metodologicamente esse objetivo, a estratégia utilizada foi a de apresentar/comparar três diferentes padrões de trajetórias que conduzem os agentes considerados aos postos de comando disponíveis pelo partido. Em termos práticos, essa estratégia analítica baseada na apresentação de três padrões de recrutamento/engajamento permitiu avaliar de que maneira a conjugação desse conjunto de determinantes (sociais, culturais e profissionais) define as posições de destaque no partido. A esse respeito, chamou aten- 
ção que os pontos de chegada - no caso, a ocupação dos postos de liderança no partido - são resultados de diferentes estratégias e itinerários dos agentes considerados pelo trabalho em tela. $O$ que também demonstrou que lidamos com um universo empírico bastante singular, no sentido de serem desprovidos do que poderíamos chamar de capital político e militante, ainda embora essas "ausências" sejam supridas por outros recursos igualmente reconhecidos no universo político, à exemplo do nível social elevado e inserção em redes de relação favoráveis, capital cultural, ocupação profissional entre outros.

O primeiro padrão apresentado intitulado "Políticos por Vocação ou tentativas de aquisição de um capital político?" teve uma importância para o estudo na medida em que apresentou um padrão de líder que se envolve no partido objetivando maiores oportunidades para disputar eleições. Dado o fato de lidarmos com um partido cujas bases institucionais demonstraram-se frágeis, o acesso às disputas eleitorais se apresenta como resultados das posições ocupadas na hierarquia do partido. Essa modalidade de engajamento permitiu demonstrar a importância da posição frente às necessidades dos "dirigentes-políticos". Em outras palavras, as relações estabelecidas a partir da posição ocupada pelos agentes considerados permite uma atuação mais eficaz, no sentido de proporcionar a oportunidade de concorrer a cargos eletivos, na medida em que, mediante a posição ocupada no partido, passa-se a ser um "selecionador" e não mais um "selecionável".

Já no segundo padrão de engajamento intitulado "Políticos por 'formação': Excelência profissional e recrutamento de líderes do PV", permitiu-nos avaliar a relação entre categorias profissionais e a ocupação de postos de liderança no partido. Para tanto, renunciou-se a dois padrões marcante entre os agentes com tais características: na primeira modalidade observou-se os que combinam recursos escolares, profissionais e econômicos com o recrutamento no partido; na segunda modalidade apresentou-se um grupo de agentes que combinam o engajamento no partido com inserção de redes de relação que possibilita a reconversão de recursos profissionais em ocupação de postos profissionais para além do espaço do partido. Padrões estes que nos permitiram observar algumas estratégias de reconversão dos recursos profissionais e de expertise.

Um dos casos apresentados mostrou a carreira ascendente de um dos líderes, tornando-se profissional reconhecido no "mercado" ao passo em que essa carreira profissional lhe permitiu um "bom" acúmulo de recursos econômicos e a inserção em espaços de "poder". Esse perfil de dirigente parece fundamental para a ascensão do partido dentro da conjuntura política local, na medida em que permite a "promoção" do partido antes e durante o "tempo da política". Não 
raro, se tornam o "homem de frente" do partido, aquele que vai à mídia, negocia alianças com líderes de outros partidos, já que os conhece e também é reconhecido, busca apoio econômico nas "altas rodas". Em outras palavras, esse tipo de líder demonstrou os sentidos que os recursos profissionais têm sobre a ascensão dos agentes aos postos de comando.

Em outra variável desse tipo de líder, chamou atenção os agentes que, por estarem engajados no PV, ampliam suas redes (sociais, profissionais) de relações, o que lhes permite se inserirem em espaços que admitam a reconversão de sua expertise. Em outras palavras, o fato de ocupar os postos de comando no partido permite o acesso a benefícios materiais, bem como a recompensas simbólicas (prestígio, poder e honra).

Por fim, a comparação ao longo do artigo entre esses diferentes padrões de trajetórias sociais que conduzem ao acesso às posições de destaque no partido, perante as divisões do grupo considerado, permitiu analisar os princípios de entrada e ascensão na hierarquia do partido estudado e permitiu também avaliar os motivos que levaram os líderes a obter rendimentos desiguais dos mesmos recursos. Isso demonstrou que as posições de liderança no partido são resultantes dos recursos de base sociais dos quais esses agentes dispõem, de modo que a posição ocupada no partido reflete, por um lado, às estruturas sociais das quais esses agentes advêm e, por outro lado, às retribuições materiais que o partido pode trazer aos seus dirigentes depende da posição social que estes ocupam.

\section{REFERÊNCIAS}

BOURDIEU, P. Le capital social. Actes de la Recherche en Sciences Sociales, Lyon, v. 31, p. 2-3, 1980.

BOURDIEU, P. O poder simbólico. Tradução de Fernando Tomaz. 11. ed. Rio de Janeiro: Bertrand Brasil, 2007.

BOURDIEU, P. O campo político. Revista brasileira de ciência política, Brasília, v. 3, n. 5, p. 193-216, 2011.

CANEDO, L. B. Herança na política ou como adquirir disposições e competências necessárias às funções de representação política (1945-1964). ProPosições, Campinas, v. 13, n. 2, p. 169-198, 2002.

CANEDO, L. B. Ritos, símbolos e alegorias no exercício profissional da política. In: CÂNEDO, L. B. (org.). O sufrágio universal e a invenção democrática. São Paulo: Estação e Liberdade, 2005. p. 477-506. 
CORADINI, O. L. Grandes famílias e elite "profissional" na medicina no Brasil. História, Ciência e Saúde - Manguinhos, Rio de Janeiro, v. 3, n. 3, p. 425-466, 1996.

CORADINI, O. L. Em nome de quem? Recursos sociais no recrutamento de elites políticas. Rio de janeiro: Relume Dumará, 2001.

DUVERGER, M. Os partidos políticos. São Paulo: Zahar, 1980.

FILLIEULE, O. Propositions Pour une Analyse Processuelle de L'engagement Individuel. Revue Française de Science Politique, v. 51, n. 1-2, p. 199-217, 2001.

GAXIE, D. Économie des partis et rétributions du militantisme. Revue française de science politique, n. 1, p. 123-154, 1977.

GAXIE, D. Les cens caché : inégalités culturelles et ségrégation politique. Paris: Éditions du Seuil, 1978.

MENDONÇA, C. Chico de Miguel: a história de um líder. / Carlos Mendonça. Aracaju: Gráfica J. Andrade LTDA, 2011.

OLIVEIRA, W. J. F. Elites dirigentes, engajamento político e retribuições do militantismo ambientalista. Tomo, São Cristóvão, n. 13, p. 201-237, 2008 a.

OLIVEIRA, W. J. F. Engajamento político, competência e elites dirigentes do movimento ambientalista. Revista de Sociologia Politica, Curitiba, v. 16, n. 30, p. 167-186, 2008b.

PALMEIRA, M. Política facção e Voto. In: PALMEIRA, M.; GOLDMAN, M. (org.). Antropologia, voto e representação política. Rio de Janeiro: Contra-Capa Livraria, 1996.

PÉCHU, C. Laissez Parler Les Objets! De l'objet des mouvements sociaux aux movements sociaux comme objets. In: FAVRE, P.; FILLIEULE, O.; JOBARD, F. (dir.). L'atelier du politiste - Théories, actions, representations. Paris: Découverte, 2007.

PETRARCA, F. O jornalismo como profissão: recursos sociais, titulação acadêmica e inserção profissional dos jornalistas no Rio Grande do Sul. 2007. 308 f. Tese (Doutorado em Sociologia) - Instituto de Filosofia e Ciências Humanas, Universidade Federal do Rio Grande do Sul, Porto Alegre, 2007.

PERISSINOTTO, R. M.; MIRIADE, A. Caminhos para o parlamento: candidatos e candidatos nas mudanças para deputado federal em 2006. Dados, Rio de Janeiro, v. 52, n. 2, p. 301-333, 2009.

RODRIGUES, L. M. Partidos, ideologia e composição social: um estudo das bancadas partidárias na Câmara dos Deputados. Rio de Janeiro: Centro Edelstein, 2009.

SAINTENY, G. Logiques d'engagement et logiques de rétribution au sein de lécologisme français. Cahiers Internationaux de Sociologie. 106 v. Paris: Presses Universitaires de France, 1999.

SEIDL, E. Disposições a militar e lógica de investimentos militantes. Pró-posições, Campinas, v. 20, n. 2, p. 21-39, 2009. 
VIEIRA, B. M. Processo de recrutamento e seleção de candidatos a cargos legislativos no Partido Verde em Sergipe na eleição de 2010. In: ENCONTRO DE CIÊNCIAS

SOCIAIS DO NORTE E NORDESTE E PRÉ-ALAS BRASIL, 15., 2012, Teresina. Anais [...]. Teresina: UFPI, 2012.

WEBER, M. A política como vocação. In: WEBER, M. Ciência e Política: duas vocações. Brasília: Editora UNB, 2003. p. 55-124. 